\title{
How to Enter the First Jhāna
}

\section{Akira Fujimoto}

\section{How can one enter the first jhāna (concentrated state)?}

Sakyamuni Buddha advocated the development of the meditation states known as jhānas. As is well known, he attained nirvana after deep meditation. This suggests that jhāna played an important role in attaining nirvana.

The questions I shall deal with in this paper are whether the Nikāya texts teach how to enter into the first meditative state of jhan a and whether the way to enter into it as taught by the texts _ if they do _ was widespread in the Indian religion of the day or specifically designed for Buddhist practitioners.

\section{Detachment}

The brief description of the way to enter into the first meditative state is given as follows.

Being thus detached from sense-desires $(k \bar{a} m a)$, detached from unwholesome states (akusala-dhamma), he (practitioner) enters and stays in the first jhāna." [DN I, 73. For quotations from DN, I use the PTS edition.]

This statement is seen to be made wherever the first state of jhäna is referred to in the Nikāyas. We thus see that the two kinds of detachment, the one from sensedesires and the other from unwholesome states, are necessary for entering into the first meditative state. Then how can one detach oneself from them?

\section{Pañca-bala (fivefold force)}

It is said that one can detach oneself from sense-desires and unwholesome states

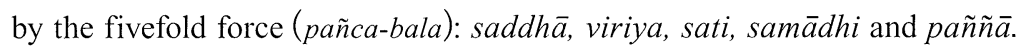




\section{3-1. saddh $\bar{a}$ ([faith] and subtle pañ $\tilde{a}$ [wisdom])}

Having heard the [Buddha's] dhamma, he (practitioner) gains faith (saddhā) in the Tathāgata (Buddha). [DN I, 62]

The faith in the Buddha, and, the understanding of dhamma by subtle wisdom (pannia) are known to be essential for the attainment of nirvana. Thus entering into the first meditative state constitutes the path to nirvana from the beginning.

\section{3-2. viriya (exertion)}

Having gone forth, he dwells protected by the restraint of the rules, ... seeing danger in the slightest faults, observing the commitments he has taken on physical and verbal deeds, devoted to the wholesome and purified life, perfected in morality. [DN I, 63]

Exertion (viriya) concerning the rules protects practitioners from committing a fault in performing physical and verbal acts, so that their lives become purified.

\section{3-3a. sati 1 (mindfulness; guard of six sense faculties)}

Practitioners have to avoid committing a fault not only in performing physical and verbal acts but also in perfoming mental acts. Merely to live upon the rules does not protect practitioners from committing a fault. They also have to guard their sense faculties of vision, audition, smell, taste, touch and thinking. The six kinds of sense faculties are guarded in one and the same manner. With respect to the sense faculty of vision, for example, it is said:

The bhikkhu, on seeing a visible object with the eye, does not grasp at its major signs (nimitta) or secondary characteristics (anuvyanjana). Because greed and sorrow, evil unwholesome states, would overwhelm him if he dwelt leaving this eye-faculty unguarded, so he practises guarding it. [DN I, 70]

What sati is and how a practitioner practises it are explained by a modern practitioner as follows:

Mindfulness is nonjudgmental observation. ... One simply takes a balanced interest in things exactly as they are in their natural states. One does not decide and does not judge. One just observes. ... The meditator observes experiences very much like a scientist observing an object under a microscope without any preconceived notions, only to see the object exactly as it is.') 
Being always mindful (sati), which means sensing anything as it is without judgment, is characteristic of Buddhist meditational practice. Such a meditational method is called vipassanā-bhāvana (insight meditation).

\section{3-3b. sati 2 (and sampajāna [clear awareness])}

The bhikkhu acts with clear awareness (sampajāna-kārī) in ... walking, standing, sitting, lying down, in waking, in speaking and in keeping silent. ... In this way, the bhikkhu is accomplished in mindfulness and clear awareness (sati-sampajannena samannāgato). [DN I, 70]

Mindfulness (sati) is always followed by clear awareness (sampajāna). Whenever one is mindful in sensing an object-moment, one can sense it as it is and moreover be fully aware of that very act of sensing.

As shown above, exertion, mindfulness and clear awareness are to be pursued by practitioners. With these factors, their concentration is increased and they are contented (santuttha) with the life characterized by no possession. It is said that practitioners with these factors are prepared to practise samatha-bhāvanā (meditation by concentration) which had already been widespread in the Indian religion before the Buddha.

\section{3-4. samādhi (concentration)}

[The bhikkhu] sits down cross-legged, holding his body erect, and concentrates on keeping mindfulness established in front of him. [DN I, 71]

To keep concentration on one single object with no interruption is necessary for entering into the first meditative state. Concentration is successfully supported by the Buddhist practice of mindfulness.

\section{3-5. pañ $\tilde{a}$ (wisdom [by removal of the five obstacles])}

A practitioner, keeping concentration, successfully removes all the five obstacles (nīvarana); worldly desires (abhijjhā), hatred (vyāpāda), sloth-and-torpor (thina-mid$d h a$ ), worry-and-flurry (uddhacca-kukkucca) and doubt (vicikicchā), which hinder the wisdom (paninā) from appearing. ${ }^{2)}$

Of the five obstacles, doubt consists of being uncertatin as to what dhammas are 
wholesome.

Abandoning doubt, he dwells with doubt left behind, without uncertainty as to what dhammas are wholesome, his mind is purified of doubt. [DN I, 71]

The doubt in question is one of the three fetters (sakkāyaditthi, vicikicchā, silabbataparāmāsa) that are to be removed at the first stage of nirvana (sotāpatti-phala). That a practitioner removes doubt in the development of concentration means that he attains part of wisdom of nirvana there.

\section{The first jhāna (concentrated state)}

When they have removed the five obstacles and attained part of wisdom, practitioners know that they have finally entered into the first meditative state of jhanna.

When he (bhikkhu) knows that these five obstacles have left him, gladness (pämujja) arises in him, from gladness comes delight (pit $i$ ), from the delight in his mind his body becomes light (käyo passambhati), with a light body he feels joy (sukha), and with joy his mind is concentrated (cittam samädhiyati). [DN I, 73]

This statement is directly followed by the above-mentioned brief description.

Being thus detached from sense-desires (kāma), detached from unwholesome states (akusala-dhamma), he enters and stays in the first jhāna, which is with thinking (savitakka) and pondering (savicāra), born of detachment, filled with delight (piti) and joy (sukha). [DN I, 73]

The first meditative state of jhāna resulting from the detachment from sense-desires and unwholesome states is that which is filled with delight and joy.

\section{Conclusion}

The way to enter into the first meditative state of jhanna was taught in the Nikāyas. One cannot say that it was commonly accepted in the Indian religion of the day. Rather, one has to say that it was specifically designed within the framework of the Buddhist path to nirvana relying on the fivefold force.

First of all, a practitioner heard the Buddha's dhamma and gained faith in the Buddha. It is to be noted that at the first stage of the path to nirvana the same is required.

The practitioner also exerts himself to protect himself from committing a fault in 
performing physical and verbal acts. In addition, he has to be mindful because mindfulness prevents greed or sorrow from occuring.

A practitioner has to remove the five obstacles which hinder wisdom from appearing by means of keeping concentration. Concentration brings about part of wisdom, and the practitioner naturally enters into the first meditative state of jhana.

To conclude: the Buddha, reforming the meditational methods which had been widespread in the Indian religion of the day, included it into his practice system within the framework of the path to nirvana.

1) Bhante Henepola Gunaratana, Mindfulness in Plain English (Boston: Wisdom Publishing, 2002), p.139.

2) "So ime panca nīvaraṇe pahāya cetaso upakkilese pannāya dubbalīkarane.."[MN I, 181, PTS edition]

〈Key words〉 jhāna, sati, vipassanāa, samādhi, nìvarana

(Former graduate student, Hiroshima University, Ph.D.)

\section{新刊紹介}

財団法人 仏教伝道協会 英訳大蔵経翻訳叢書

THE VAIROCANĀBHISAMBODHI SŪTRA

（大毘盧遮那成佛神變加持經）

Translated by Rolf W. Giebel

B5変形判＼cjkstart定価5,500円 